\title{
Initiation factor modifications in the preapoptotic phase
}

\author{
SJ Morley ${ }^{*, 1}$, MJ Coldwell ${ }^{1}$ and MJ Clemens ${ }^{2}$ \\ ${ }^{1}$ Department of Biochemistry, School of Life Sciences, University of Sussex, \\ Falmer, Brighton BN1 9QG, UK \\ 2 Translational Control Group, Biochemistry and Immunology, Department of \\ Basic Medical Sciences, St. George's Hospital Medical School, Cranmer \\ Terrace, London SW17 ORE, UK \\ * Corresponding author: S Morley, Department of Biochemistry, School of Life \\ Sciences, University of Sussex, Falmer, Brighton BN1 9QG, UK. \\ Tel: + 44-1273-678544; Fax: + 44-1273-678433; \\ E-mail: s.j.morley@sussex.ac.uk
}

Received 17.12.04; revised 18.1.05; accepted 18.1.05

Edited by A Willis

\begin{abstract}
Recent studies have identified several mechanistic links between the regulation of translation and the process of apoptosis. Rates of protein synthesis are controlled by a wide range of agents that induce cell death, and in many instances, the changes that occur to the translational machinery precede overt apoptosis and loss of cell viability. The two principal ways in which factors required for translational activity are modified prior to and during apoptosis involve (i) changes in protein phosphorylation and (ii) specific proteolytic cleavages. In this review, we summarise the principal targets for such regulation, with particular emphasis on polypeptide chain initiation factors elF2 and elF4G and the elF4E-binding proteins. We indicate how the functions of these factors and of other proteins with which they interact may be altered as a result of activation of apoptosis and we discuss the potential significance of such changes for translational control and cell growth regulation.

Cell Death and Differentiation (2005) 12, 571-584.

doi:10.1038/sj.cdd.4401591
\end{abstract}

Keywords: apoptosis; elF2; elF4G; elF4E-binding proteins

Abbreviations: $\mathrm{HRI}$, haemin-regulated inhibitor; PABP, poly(A)binding protein; cbp, cap-binding proteins; IFN, interferon; TRAIL, TNF $\alpha$-related apoptosis-inducing ligand

\section{Introduction}

In recent years, a great deal of effort has been focused on questions concerning the highly regulated processes of cell growth, proliferation and programmed cell death (apoptosis). Hormones, growth factors and other ligands exert pleiotropic effects through activation of specific cell-surface receptors, and via transmembrane signalling and activation of common protein kinase/phosphatase cascades inside the cell. These in turn trigger an array of cellular responses, culminating in either cell growth and division, differentiation or cell death. One of the obligatory, early responses in all of these processes is a modulation of the rate of protein synthesis, mediated by changes in the phosphorylation of translation initiation factor polypeptides, regulation of the association of these factors into functional complexes or targeted cleavage of factors by cellular proteases (reviewed in Morley ${ }^{1}$ ). Until recently, relatively little attention has been focused on the changes in protein synthesis that accompany the commitment and execution phases of apoptosis. This is in spite of the fact that the induction of apoptosis is associated with a rapid and substantial (but incomplete) inhibition of protein synthesis in several cell types (reviewed in Clemens et al. ${ }^{2}$ ). Here, we will discuss the most thoroughly studied examples of such regulation and will summarise the current views on the significance of this control for both global and mRNA-specific protein synthesis.

\section{Apoptotic Targets}

\section{elF2}

Initiation factor elF2 is an important target for regulation by several physiological stresses, including those that induce apoptosis. During the initiation phase of translation, elF2 mediates the binding of the initiator Met-tRNA $A_{i}$ to the $40 \mathrm{~S}$ ribosomal subunit, resulting in the formation of a functional 435 preinitiation complex (reviewed in Hershey and Merrick ${ }^{3}$ ). This process requires the formation of a ternary complex between elF2, Met-tRNA $A_{i}$ and GTP. The 435 complex associates with mRNA, in a process requiring several other initiation factors, ${ }^{3,4}$ and locates the initiating AUG codon, usually as a result of ribosomal scanning from the $5^{\prime}$-end of the mRNA. During the subsequent joining of the $60 \mathrm{~S}$ ribosomal subunit, the GTP that is associated with the elF2 molecule is hydrolysed to GDP and phosphate, concomitant with the dissociation of the initiation factor from the ribosome. The GDP remains associated with the elF2 and has to be exchanged for another molecule of GTP in a reaction catalysed by the guanine nucleotide exchange factor, elF2B. ${ }^{5}$ The regulation of elF2 activity is most frequently a consequence of changes in the phosphorylation state of its $\alpha$ subunit, the smallest of three subunits, on Ser- 51 . This leads to an increased affinity of the initiation factor for elF2B, thus increasing the proportion of the latter that is trapped as an inactive complex with phosphorylated elF2 and GDP. ${ }^{3-5}$

A small family of protein kinases, all with specificity for elF2 $\alpha$ Ser-51, is responsible for the phosphorylation of this protein. Each of the members of the family can be activated 
by a specific set of cellular stress conditions. The kinases are as follows: HRI (haemin-regulated inhibitor), an enzyme prominent in red blood cell precursors that can be activated by iron or haem deficiency, heat-shock, osmotic and oxidative stress, nitric oxide and heavy metals; PKR, an interferon (IFN)-inducible, double-stranded RNA-dependent protein kinase that is activated during virus infections, as well as in response to many proapoptotic stimuli; the endoplasmic reticulum protein kinase PERK, regulated by the accumulation of unfolded proteins in the ER and a major player in the unfolded protein response; and $\mathrm{mGCN} 2$, the mammalian homologue of the Saccharomyces cerevisiae protein kinase that responds to amino-acid starvation (reviewed in Sonenberg and Dever ${ }^{4}$ and Kaufman ${ }^{6}$ ). It is possible that any of these enzymes may be activated by individual apoptotic stimuli, but the best evidence so far concerns the role of PKR in cell death regulation (see below).

\section{The elF4F complex}

The mRNA binding stage of translation is also a major site of regulation, requiring the activity of elF4F, a heterotrimeric complex comprising elF4E, elF4GI or elF4GII and elF4A (Figure 1a). In terms of regulatory significance, this second phase of initiation has the potential to modulate both the overall rate of protein synthesis and the selective recruitment of specific mRNAs for translation. This step can be modulated during apoptosis both by the phosphorylation of key initiation factors and by changes in the levels and integrity of these factors (reviewed in Morley ${ }^{1}$ ).

A crucial step in mRNA binding is recognition of the $5^{\prime} \mathrm{m}^{7}$ GpppG cap structure present on all cellular mRNAs by the phosphoprotein elF4E (reviewed in Morley ${ }^{1}$ and Hershey and Merrick $^{3}$ ). The structure of elF4E resembles a cupped hand, ${ }^{7}$ with the concave surface of the protein binding to the cap, while the convex surface interacts with elF4G. ${ }^{8-10}$ The latter is in turn bound to elF4A, the third subunit of the heterotrimeric elF4F complex. elF4E can bind the $\mathrm{m}^{7} \mathrm{GTP}$ cap structure alone, but when it is part of the elF4F complex, cap binding is greatly enhanced (reviewed in Morley, ${ }^{1}$ Pain, ${ }^{11}$ Dever, ${ }^{12}$ Preiss and Hentze, ${ }^{13}$ Gingras et al. ${ }^{14,15}$ and Raught et $\left.a .^{16}\right)$. Phosphorylation of elF4E by the MAP kinase integrating kinases $(\mathrm{Mnk} 1 / 2)$ in response to activation of the ERK and p38 MAP kinase pathways can also modulate the affinity of elF4E for the $\mathrm{m}^{7} \mathrm{GTP}$ cap. ${ }^{15}$ Biophysical studies suggest that the phosphorylation of elF4E actually decreases its cap-binding affinity, increasing the rate of dissociation of elF4E from an immobilised $\mathrm{m}^{7}$ GTP cap structure. ${ }^{17}$ In addition, the availability of elF4E for interaction with elF4G is controlled by a family of small elF4E-binding proteins (the 4E-BPs), which act as competitive inhibitors of the interaction between elF4E and elF4G. ${ }^{14}$ The extent of sequestration of elF4E by 4E-BP1 and $4 \mathrm{E}-\mathrm{BP} 2$ is determined by the state of phosphorylation of the $4 \mathrm{E}-\mathrm{BPs}$, which is regulated by a number of signalling pathways. ${ }^{14,18}$ Phosphorylation at multiple sites strongly reduces the affinities of the $4 \mathrm{E}-\mathrm{BPs}$ for elF4E $\mathrm{E}^{9,19}$ (Figure 2).

Many studies suggest that translation initiation is deregulated during tumorigenesis, ${ }^{20,21}$ and it is of interest that the level of expression of elF4E is often abnormally high in malignant cell lines and naturally occurring tumours. ${ }^{22,23}$ Moreover, the experimental overexpression of elF4E can cause malignant transformation (reviewed in Zimmer et al. ${ }^{23}$ ). The effects of elF4E overexpression can result in the inhibition of apoptosis. ${ }^{24,25}$ Conversely, enhanced expression or activity of the 4E-BPs inhibits cell growth, counteracts the transforming potential of elF4E and sensitises cells to apoptosis. This depends on the ability of the 4E-BPs to sequester elF4E. ${ }^{26} \mathrm{~A}$ likely explanation for these phenomena is that high levels of elF4E increase the translational efficiencies of mRNAs with roles in the promotion of cell proliferation or inhibition of apoptosis, whereas the 4E-BPs have the opposite effect. Examples of mRNAs regulated in this way are the src family member Ick, ${ }^{27} \mathrm{c}-\mathrm{Myc},{ }^{28}$ cyclin D $1^{29}$ and VEGF. ${ }^{30}$

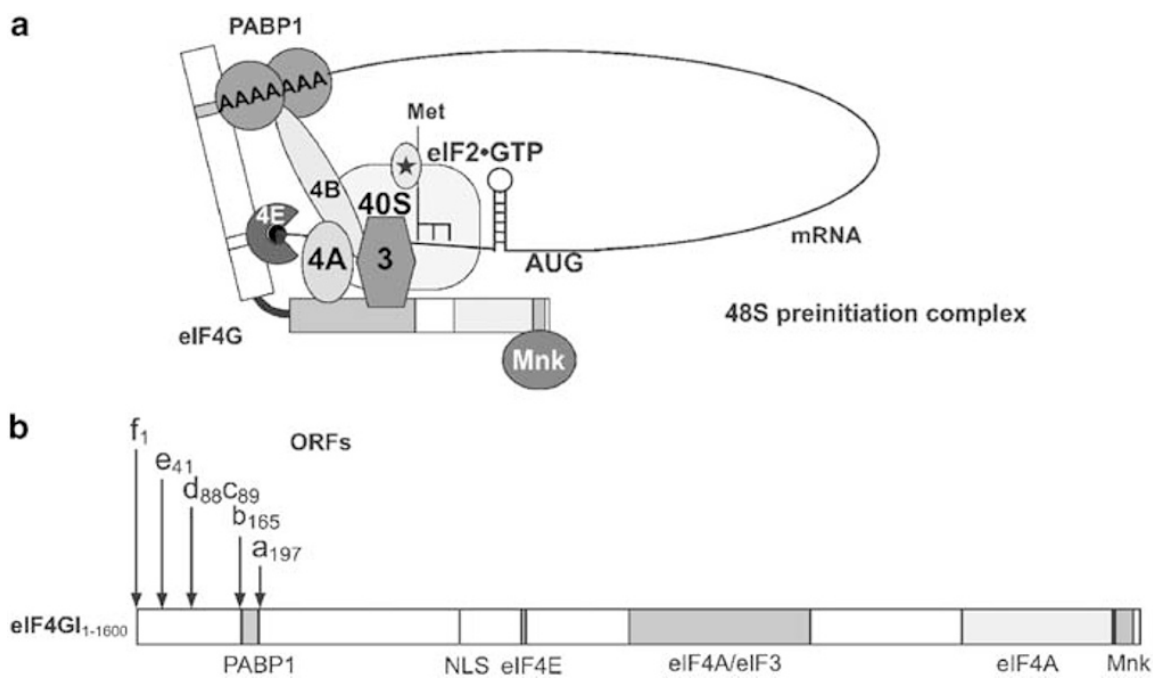

Figure 1 Role of elF4G in translation initiation. (a) elF4G plays a central role in assembly of the $48 \mathrm{~S}$ preinitiation complex, where the black disc represents the mRNA cap structure. (b) Isoforms of elF4GI arise through alternative translation initiation and differ in sequence at the N-terminus. All numbering of elF4GI protein sequences is based on the $\mathrm{N}$ terminally extended sequence described in Bradley et al. ${ }^{53}$ and Byrd et al. ${ }^{54}$ 


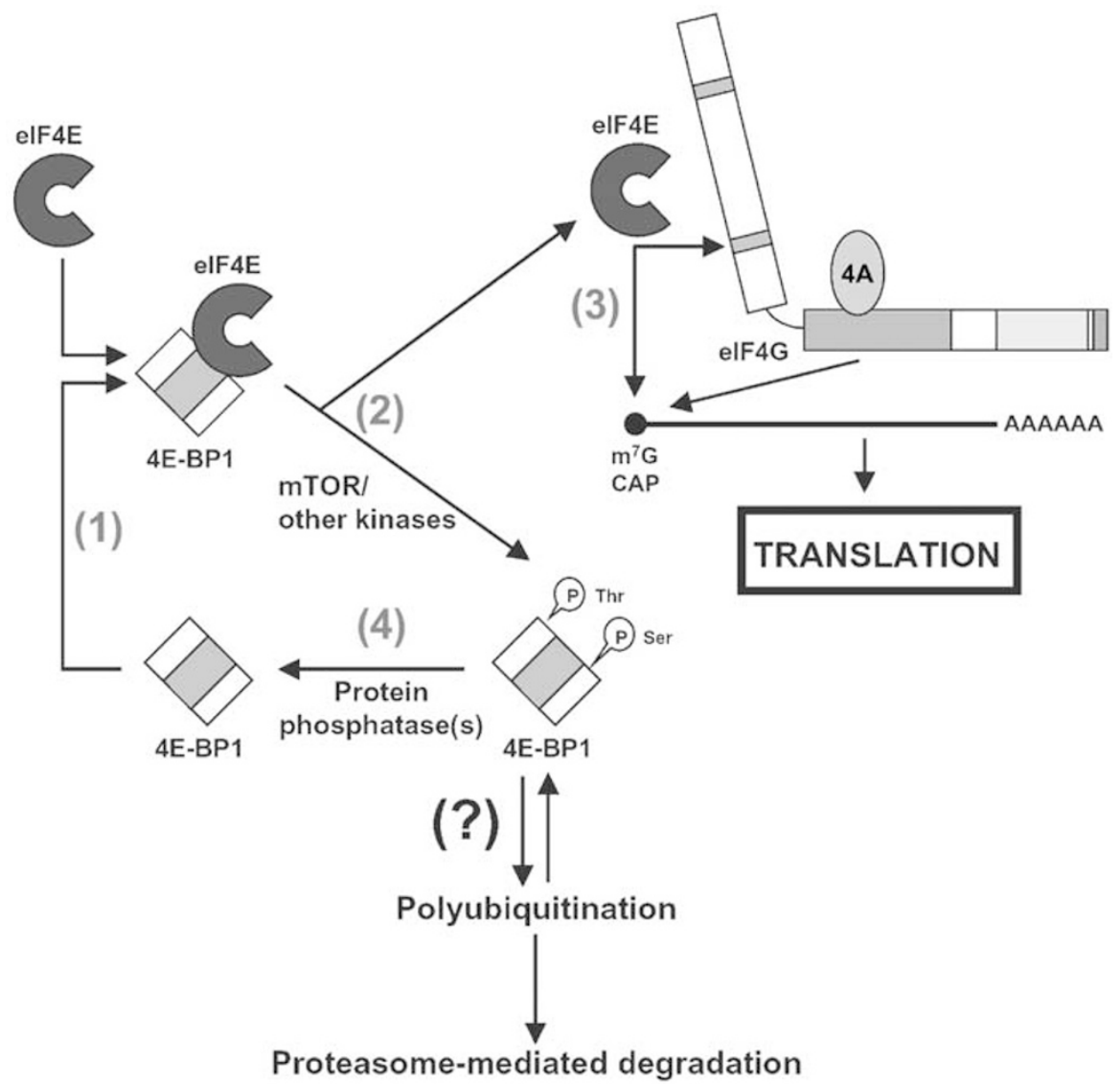

Figure 2 Model for regulation of elF4E availability by 4E-BP1 phosphorylation and degradation. Hypophosphorylated 4E-BP1 binds to elF4E and prevents the latter from interacting with elF4G and participating in cap-dependent initiation. (1) 4E-BP1 is phosphorylated by an mTOR-dependent mechanism (2), resulting in its dissociation from elF4E. The elF4E can then interact with elF4GI or II (3). Phosphorylated 4E-BP1 can be dephosphorylated by protein phosphatase(s) (4) and can then rebind elF4E. Conditions that promote apoptosis lead to early changes in the state of phosphorylation of 4E-BP1 (preceding any loss of cell viability or overt cell death); this may be due to both inhibition of mTOR (and other protein kinases) and to activation of protein phosphatases. As well as causing a net dephosphorylation of 4E-BP1, some treatments (e.g. exposure of cells to TRAIL) lead to the accumulation of the protein. It remains to be determined whether the state of phosphorylation of 4E-BP1 regulates other post-translational modifications such as polyubiquitination that may signal the degradation of this protein

Initiation factor elF4A is also an important component of the elF4F complex. This factor is an RNA-dependent ATPase, and is the prototypic member of the DEAD box helicase family (reviewed in Morley, ${ }^{1}$ Hershey and Merrick ${ }^{3}$ and Raught et al. ${ }^{16}$ ). Mammalian elF4A exists in three highly similar isoforms (elF4AI, elF4All, elF4AIII) that appear to differ in tissue distribution and developmental regulation. ${ }^{31-35}$ It has been suggested that elF4AI or II functions primarily as a subunit of the elF4F complex, with elF4A being required to recycle through the complex during translation. ${ }^{3,15,36}$ In contrast, elF4Alll binds spliced mRNA in the exon junction complex and is required for nonsense-mediated mRNA decay, but plays no role in mRNA translation. ${ }^{37-39}$ In conjunction with elF4B, elF4A is believed to function to promote unwinding of mRNA secondary structure, ${ }^{36,40}$ being absolutely required for mRNA-ribosome binding both in its free form and as part of the elF4F complex. ${ }^{36}$ Furthermore, elF4AI/II is essential for translation of all mRNAs and for growth in yeast. ${ }^{41}$ elF4B is also required for mRNA binding to ribosomes and it stimulates the RNA helicase activity of elF4A in vitro. ${ }^{3,42}$ Three potential regulatory domains of elF4B are revealed in the protein sequence: an RNA-binding domain (RRM), a hydrophilic region (DRYG), which mediates binding of a truncated form of elF4B to the elF3a/p170 subunit of the ribosome-associated elF3 (Methot et al.: ${ }^{43}$ see below) and a serine-rich region at the C-terminus. ${ }^{44}$ In vitro studies with mutant proteins have indicated that the RNA-binding domain alone is insufficient to support interaction with mRNA, but may localise elF4B to the ribosome. ${ }^{45} \mathrm{~A}$ region in the DRYG domain, however, is important for both RNA binding and the ability of elF4B to stimulate the helicase activity of elF4A. ${ }^{46}$ Thus, elF4B has been postulated to act directly by binding to the $5^{\prime}$ UTR of the mRNA and to the ribosome, and/or indirectly via its interaction with elF3 to promote the mRNA/rRNA/initiator tRNA interaction at the AUG codon. ${ }^{3}$ An elF4B-related protein, termed elF4H, has been identified that possesses an RRM domain but lacks the corresponding DRYG region. ${ }^{47}$ elF4H can substitute for elF4B in a reconstituted translation system, increases the affinity of elF4A for RNA, stimulates elF4A helicase activity ${ }^{48}$ and may function to 
stabilise directly conformational changes in elF4A that occur during initiation. ${ }^{3}$

Initiation factors elF4GI and II, which are the largest components of elF4F complexes, share $46 \%$ identity at the amino-acid level. Both proteins can act as adapter molecules on which many other initiation factors can bind (Figure 1a). ${ }^{1,14,49}$ In addition, two families of proteins with sequence homology to elF4G have been identified, referred to as p97/NAT1/DAP5 and Paip-1 (reviewed in Gingras et al., ${ }^{14,15}$ Raught et al. ${ }^{16}$ and Morley et al. ${ }^{50}$ ). The original cDNA clone of elF4GI obtained from a human brain cDNA library ${ }^{51}$ was extended in a later study ${ }^{52}$ to identify an N-terminal PABP binding site. More recently, two groups independently discovered a further $\mathrm{N}$-terminal extension of 40 amino acids, finally identifying the longest possible open-reading frame of elF4GI. ${ }^{53,54}$ These studies suggest that five isoforms of elF4GI exist in cells, generated by alternative translation initiation (Figure 1b). However, little is known as to the function of these different isoforms in the cell. Along with the interactions with elF4E and elF4A, the elF4Gs also bind RNA, the multisubunit elF3, the elF4E kinase Mnk1 and the cytoplasmic form of PABP in the steady-state translation initiation complex (Figure 1a). In addition, elF4GI has been implicated in a pioneer round of translation for newly transcribed mRNA, via interactions with the nuclear cap-binding proteins (cbp), cbp80 and cbp20. ${ }^{55,56}$ PABP binds directly to a domain in the $\mathrm{N}$-terminus of mammalian elF4G via a conserved sequence of basic amino acids. This association is believed to mediate the circularisation of mRNA and promote the poly $(A)$ and PABP-dependent stimulation of mRNA translation. ${ }^{57-65}$ The binding of PABP to elF4G has also been suggested to increase the helicase activity of elF4F, ${ }^{66}$ while the association of elF4GI with elF4E markedly enhances the binding of the latter to the mRNA cap. ${ }^{67}$ Phosphorylation of elF4GI, possibly promoting conformational changes in the protein, ${ }^{68}$ has been associated with the upregulation of cell growth. ${ }^{50,69-73}$ In contrast, elF4GIl phosphorylation is increased primarily at the $\mathrm{G}_{2} / \mathrm{M}$ phase of the cell cycle, ${ }^{74,75}$ but roles for these phosphorylation events in modulating translation rates remain unclear.

\section{Initiation factor elF3}

Initiation factor elF3 was first isolated and purified as a high molecular weight complex from rabbit reticulocytes. $^{3}$ The mammalian factor (approx. $600 \mathrm{kDa}$ ) contains at least 12 nonidentical protein subunits, designated a-I in the order of decreasing molecular weight. ${ }^{76}$ Specific functions for mammalian elF3 have been identified by a variety of in vitro experiments, ${ }^{3}$ showing that it binds directly to $40 \mathrm{~S}$ ribosomal subunits and affects the association/dissociation of $80 S$ ribosomes. In addition, elF3 promotes the binding of Met-tRNA $A_{i}$ and mRNA to the $40 \mathrm{~S}$ ribosome, and binds directly to elF1, elF4B, elF4G and elF5, clearly playing a critical role in translation initiation.

It has been proposed that it structurally organises other translational components on the surface of the $40 \mathrm{~S}$ ribosome. ${ }^{77}$

\section{Modification of Translation Initiation Factors during Apoptosis}

The downregulation of translation rates in apoptosing cells was initially observed in several independent studies (e.g. Deckwerth and Johnson, ${ }^{78}$ Zhou et al. ${ }^{79}$ and Scott and Adebodun ${ }^{80}$ ). However, it is only more recently that the underlying changes to the translation machinery that take place during apoptosis have been elucidated (Figures 3 and 4). For example, treatment of Jurkat T cells with anti-Fas antiserum results in a $60-70 \%$ decrease in the rate of protein synthesis within $2-4 h^{81}$ and a loss of cell viability. The inhibition of protein synthesis is associated with a substantial decrease in the proportion of ribosomes in polysomes, ${ }^{79,81}$ strongly suggesting that there is a block at the stage of polypeptide chain initiation at these early times. These events are prevented by the cell-permeable caspase inhibitor, z.VAD.FMK, indicating that caspase activity is required. However, the mechanisms involved in translational regulation during apoptosis depend on the nature of the apoptotic inducer (e.g. the downregulation of translation caused by the DNA-damaging agent etoposide is zVAD.FMK insensitive ${ }^{81}$ ).
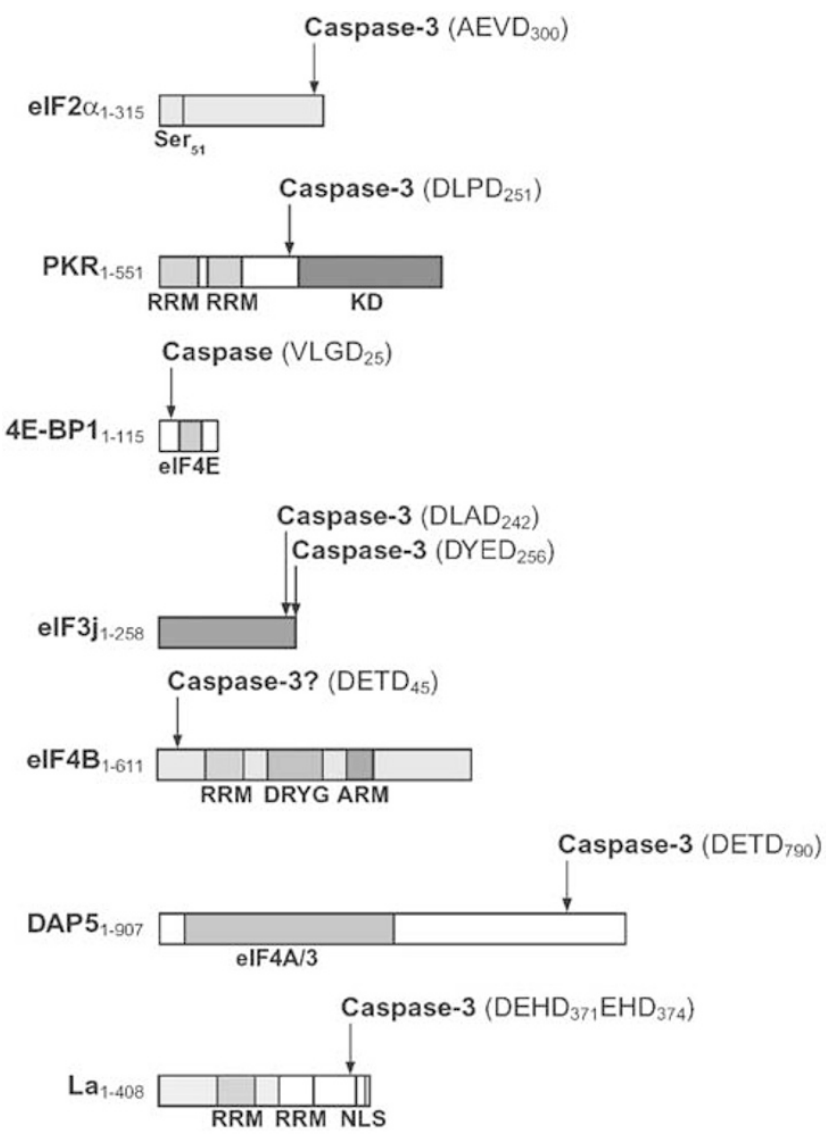

Figure 3 Modifications of other factors involved in translation initiation during apoptosis. See the text and references therein for details. Abbreviations: RRM, RNA recognition motif; KD, kinase domain; DRYG, region rich in aspartate, arginine, tyrosine and glycine; ARM, arginine-rich motif; NLS, nuclear localisation signal 

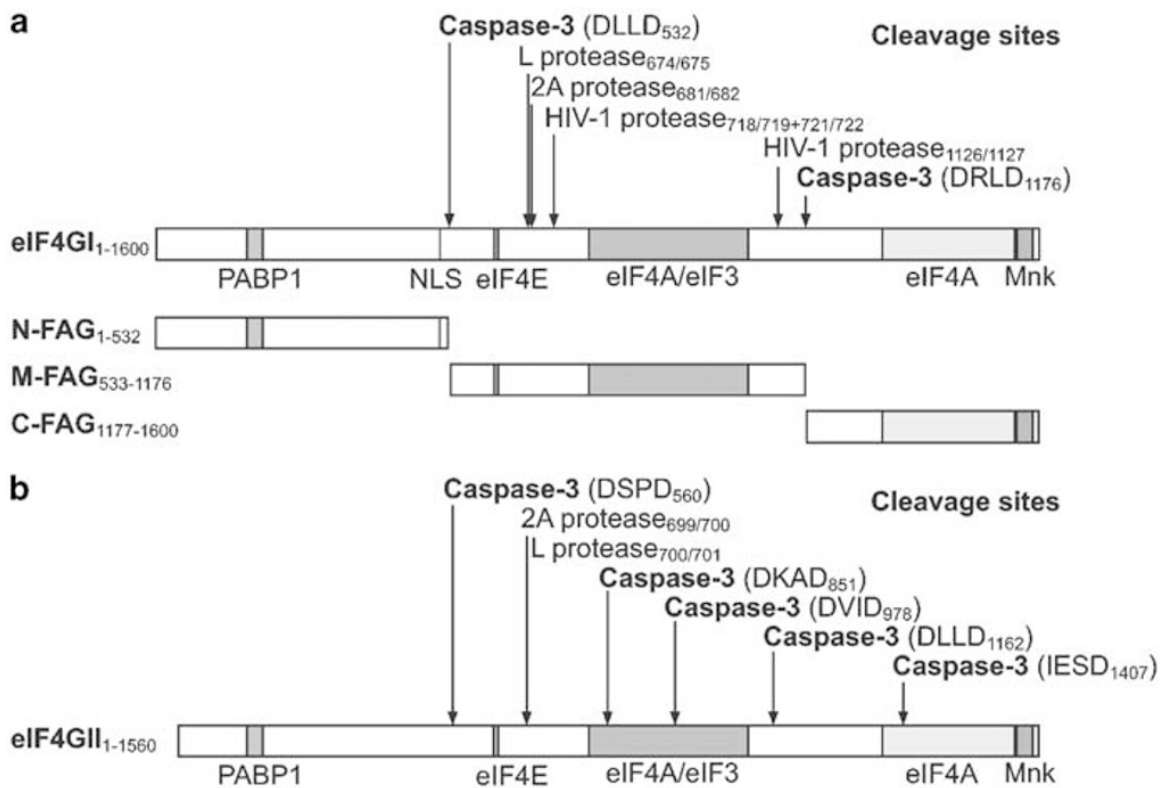

Figure 4 Caspase-mediated cleavage of elF4G. (a) Cleavage of elF4Gl by caspase-3 generates three discrete fragments, designated 'Fragments of Apoptotic cleavage of elF4G' (FAGs). These are different from the fragments produced after cleavage by picornaviral (L or 2A) proteases and HIV-1 protease. (b) Additional caspase cleavage sites are found in the elF4GII molecule

\section{elF2}

Initiation factor elF2 is regulated during apoptosis in two ways. The extent of phosphorylation of the $\alpha$ subunit of this factor is often found to be increased in cells following exposure to a variety of proapoptotic stimuli. ${ }^{82,83}$ In principle, any of the four protein kinases that phosphorylate Ser-51 on elF2 $\alpha$ could be responsible, but $\mathrm{PKR}$ is the strongest candidate because this enzyme has an important role in promoting cell death. ${ }^{84,85}$ PKR is one of several gene products induced by IFN treatment. It is involved in both the antiviral and antitumour effects of these cytokines and appears capable of regulating both cell proliferation and apoptosis (reviewed in Clemens ${ }^{21}$ ). Studies with embryonic fibroblasts deficient in PKR have shown that this enzyme is essential for changes in the protein synthetic machinery associated with the response to TNF $\alpha .{ }^{83}$ In fact, the effects of the TNF $\alpha$ family on translation appear to require the participation of both PKR-mediated and caspasedependent events. Consistent with these observations, we have found that the $\alpha$ subunit of elF2 becomes highly phosphorylated in cells exposed to TNF $\alpha$ or TRAIL (TNF $\alpha$ related apoptosis-inducing ligand), at times preceding any loss of cell viability or the onset of cell death.

TRAIL inhibits cell growth and induces programmed cell death in a wide variety of tumour types, ${ }^{86-90}$ and acts preferentially on malignant cells. ${ }^{91,92}$ A major effect of the association of this cytokine with its cell-surface receptors is the activation of caspase-8..$^{93-95}$ It is interesting to note, therefore, that in TRAIL-treated MCF-7 cells, the phosphorylation of elF2 $\alpha$ is itself a caspase-dependent process, which can be prevented by treatment of the cells with either the broad specificity caspase inhibitor z.VAD-FMK or the caspase-8-specific inhibitor z.IETD-FMK (IW Jeffrey and MJ Clemens, unpublished data). In contrast, there is no requirement for caspase- 8 for the transient phosphorylation of elF2 $\alpha$ in Jurkat cells following activation of the Fas (CD95) receptor. $^{82}$

In view of the PKR requirement for the effects of TNF $\alpha$ on protein synthesis in fibroblasts ${ }^{83}$ and the marked ability of TRAIL to enhance the phosphorylation of elF2 $\alpha$ in MCF-7 cells, it is of interest to know whether PKR is activated following treatment of cells with TNF $\alpha$ or TRAIL. Immunoblotting of cell extracts with an antibody that only recognizes PKR that is phosphorylated at Thr-451, a site associated with the activation of the protein kinase, has suggested that TRAIL does not induce the activation of full-length PKR. However, it does result in the appearance of a PKR cleavage product of approximately $43 \mathrm{kDa}$ that is phosphorylated at this site (IW Jeffrey and MJ Clemens, unpublished data). Although not formally proven to date, this may correspond to a catalytically active fragment of PKR; such a fragment, generated by caspase cleavage and highly active as an elF2 $\alpha$ kinase, can arise as a result of the removal of the inhibitory dsRNA-binding domain from the enzyme. ${ }^{96}$

In addition to changes in elF2 $\alpha$ phosphorylation, in cells treated with TRAIL and some other proapoptotic agents, a small fraction of elF2 $\alpha$ is often cleaved to give rise to a $\mathrm{C}$ terminally truncated product ${ }^{97,98}$ (Figure 3). The physiological significance of this cleavage is unclear, however, since only a small proportion of the elF $2 \alpha$ population ever seems to be modified in this way (but see later in this review for a discussion of this point).

\section{elF4GI and elF4GII}

Many studies ${ }^{81,82,99-105}$ have demonstrated that both elF4GI and elF4GII are targets for specific degradation during apoptosis (reviewed in Morley ${ }^{1}$ and Clemens et al. ${ }^{2}$ ). Deprivation of serum growth factors, activation of the Fas receptor, or 
treatment of a variety of cells with cycloheximide, MG132, cisplatin, etoposide, TNF $\alpha$ or TRAIL leads to the inhibition of translation and the progressive degradation of elF4GI and elF4GII. In contrast to the cleavage of elF4G during picornavirus infection, ${ }^{106}$ the loss of elF4GI and elF4GII during apoptosis occurs with similar kinetics. ${ }^{82,99,101,104}$ Under the same conditions, there are no major decreases in the levels of several other initiation factors including elF4E, elF4A and PABP. ${ }^{82,101}$ However, it has been shown recently that PABP can be cleaved by a partially caspase-dependent mechanism, although it is not a substrate for caspase-3 itself. ${ }^{107}$ In most (but not all) cases, both the inhibition of translation and the cleavage of elF4G can be prevented by cell-permeable caspase inhibitors, with the activity of the effector caspase, caspase-3, being both necessary and sufficient for the proteolysis of elF4GI and elF4GII in vitro and in vivo. ${ }^{81,82,99,100,104}$

The cleavage of elF4GI and elF4GIl by picornaviral proteases bifurcates the molecule, separating the cap-binding component from the ribosome-binding portion (Figure 4) and providing an obvious mechanism for the inhibition of capdependent translation. In contrast, HIV-1 protease only cleaves elF4GI, cutting the protein into novel, distinct fragments that serve to inhibit both cap-dependent and IRES-driven translation. ${ }^{108,109}$ However, the cleavage of the elF4Gs by intracellular caspases produces considerably different fragments. Caspase-3 cleaves elF4GI at two sites, the first being between amino acids 532 and 533 downstream of a DLLD sequence and the second between amino acids 1176 and 1177, downstream of a DRLD sequence (Figure 1b). Initial cleavage events at either of these two sites generate intermediate fragments migrating at 120 and $150 \mathrm{kDa}$, respectively. The three distinct breakdown products of elF4GI resulting from the two cleavages have been termed Fragments of Apoptotic cleavage of elF4G (FAGs) ${ }^{99,102}$ and designated N-FAG, M-FAG and C-FAG (Figure 4a). During apoptosis, dephosphorylated elF4E is maintained in a modified elF4F complex with M-FAG, which is in turn still able to bind elF4A, elF3 and $40 S$ ribosomes. ${ }^{82,101}$ This complex was proposed to maintain some form of cap-dependent translation and an independent study defined a fragment closely corresponding to $M-F A G$ as the minimal sequence of elF4GI required to bind mRNA to ribosomes in an in vitro assay. ${ }^{110}$

\section{E-BP1}

In proliferating cells, the 4E-BPs are phosphorylated and remain dissociated from elF4E. In contrast, under conditions that block cell proliferation or induce apoptosis, 4E-BP phosphorylation decreases and the 4E-BPs associate with elF4E. Many physiological stresses and growth-regulatory conditions affect the state of phosphorylation of the 4EBPs. ${ }^{14,111-113}$ Prominent among the agents that both cause dephosphorylation of 4E-BP1 and induce apoptosis are the broad specificity protein kinase inhibitor staurosporine, TRAIL, Fas ligand, DNA damage inducers and activated p53. ${ }^{21,82,83}$ Previous studies have shown that TRAIL inhibits overall translation by a mechanism that involves increased association of elF4E with 4E-BP1, and that these effects precede the development of overt cell death and loss of viability. ${ }^{83}$ Consistent with its effects on the binding of 4E-BP1 to elF4E, TRAIL also causes decreased binding of elF4GI to elF4E (I Jeffrey and MJ Clemens, unpublished data).

A key factor involved in promoting 4E-BP phosphorylation is the rapamycin-sensitive enzyme, mammalian target of rapamycin (mTOR; ${ }^{113}$ ) and the ability of rapamycin to inhibit 4EBP phosphorylation is important for the proapoptotic effect of this drug. ${ }^{114}$ The levels of 4E-BPs that are expressed can influence cellular sensitivity to rapamycin, ${ }^{115}$ and recent developments in assessing rapamycin and its derivatives as potential anticancer agents ${ }^{116,117}$ have included strategies targeted specifically at mTOR-mediated regulation of the 4E-BPs. ${ }^{118}$ However, there is also evidence that some changes in the phosphorylation of 4E-BP1 (e.g. those seen after activation of p53) are independent of rapamycinsensitive mTOR (C Constantinou and MJ Clemens, unpublished data).

There is also evidence that the levels of the 4E-BPs may change with differing physiological circumstances. For example, following fertilization of sea urchin eggs, 4E-BP1 is rapidly degraded, and this coincides with an increase in the rate of protein synthesis during early embryogenesis in this system. ${ }^{119}$ Conversely, the level of 4E-BP1 increases rapidly and substantially when either human lymphoma or breast cancer cell lines are treated with TRAIL (I Jeffrey, A Elia and MJ Clemens, unpublished data). We do not yet know the mechanism of the TRAIL-mediated accumulation of 4E-BP1. Nevertheless, there are several precedents for a relationship between changes in protein phosphorylation and protein stability. Examples are the destabilization of the inhibitor of $\mathrm{NF} \kappa \mathrm{B}\left(\mathrm{I}_{\kappa} \mathrm{B}\right)$, as a result of phosphorylation-dependent polyubiquitination and subsequent degradation via the proteasome pathway, ${ }^{120,121}$ and regulation of the turnover of $\beta$ catenin and p53. ${ }^{122,123}$ However, it remains to be established whether 4E-BP1 is ubiquitinated prior to its degradation (Figure 2) and whether the phosphorylation status of 4E-BP1 influences its turnover in a TRAIL-sensitive manner.

TRAIL is by no means the only inducer of apoptosis that affects 4E-BP1 phosphorylation and/or stability. Both dephosphorylation and caspase-mediated cleavage of 4E-BP1 have been shown to occur in cells exposed to staurosporine and the DNA-damaging agent etoposide. ${ }^{124-126}$ Cleavage occurs at Asp-24, close to the $\mathrm{N}$-terminus of the protein (Figure 3 ). The activation of $\mathrm{p} 53$ also results in the cleavage of $4 \mathrm{E}-\mathrm{BP} 1$, but in this case, the cleavage is a z-VAD.FMK-insensitive event, suggesting that it is mediated by another type of protease (C Constantinou and MJ Clemens, unpublished data). However, the characteristics of the caspase-mediated and caspaseindependent cleavage products of 4E-BP1 so far appear identical in all respects, and it is possible that the region of the protein close to Asp-24 is a particularly vulnerable site for proteolysis. Whether the site-specific cleavage(s) within this region of 4E-BP1 have a functional relationship to the turnover of the protein as a whole remains to be established.

\section{elF4B and elF3j (p35)}

Cleavages of elF4B and the p35 (j) subunit of elF3 have also been observed during apoptosis, with none of the other subunits of elF3 being affected. ${ }^{101}$ However, these 
caspase-3-mediated events occur with delayed kinetics relative to that seen for elF4GI. As with elF4GI, caspase-3 is able to cleave both elF3j and elF4B in vitro; however, elF4B is also cleaved during apoptosis in MCF-7 cells lacking caspase-3, suggesting that other caspases may be involved in vivo. ${ }^{83}$ elF4B is cleaved between amino acids 45 and 46 after a DETD sequence to produce a $60 \mathrm{kDa}$ cleavage product (Figure 3 ). This cleavage site is in the $\mathrm{N}$-terminal domain of the protein in a region that is required for its interaction with PABP. The $\mathrm{N}$ terminally truncated fragment of elF4B was still able to coisolate with the mRNA cap-binding elF4F complex ${ }^{101}$ and still contains the DRYG motif that is essential for self-association of elF4B molecules and for its interaction with the largest $170 \mathrm{kDa}$ subunit of elF3 (elF3a). ${ }^{127}$

The appearance of the $\Delta$ elF3j fragment (Figure 3), which is only slightly smaller than the intact protein, is evident within $4 \mathrm{~h}$ of cycloheximide-induced apoptosis of BJAB cells, with complete conversion to the truncated form evident at later times. ${ }^{101}$ The main caspase cleavage site was mapped between amino acids 242 and 243, after a DLAD sequence, leading to the loss of the final 16 amino acids of the molecule (Figure 3). In vitro experiments also indicated that caspase-3 has the ability to cleave just two amino acids from the C-terminus of the molecule. ${ }^{101}$ Although the exact function of the elF3j subunit in the elF3 multisubunit complex remained unresolved for a number of years, ${ }^{3,128,129}$ recent studies have determined that it has a central role in mediating the stable association of elF3 with the $40 \mathrm{~S}$ ribosome. ${ }^{77}$ elF3j that has been processed to the shorter form by caspase- 3 shows a dramatically reduced affinity for the $40 \mathrm{~S}$ ribosome and consequently does not efficiently recruit elF3 to the $40 \mathrm{~S}$ ribosome. $^{77}$

\section{Other factors that regulate initiation}

A gene variously called p97, DAP-5 or NAT $1^{130-132}$ encodes a protein that is homologous to the central and C-terminal parts of elF4GI. This protein acts to protect HeLa cells against IFN- $\alpha$-induced apoptosis. ${ }^{131}$ In addition, recent studies have indicated that while DAP5 is not important for general translation, DAP5 function is required for controlling gene expression during cellular differentiation. ${ }^{133}$ As with elF4GI, DAP5 is also cleaved during apoptosis, downstream of DETD $_{790}$ (Figure 3), yielding an N-terminal fragment competent to bind elF3 and elF4A, which is distinct from M-FAG as it lacks the elF4E binding site. ${ }^{134}$

The La (SS-B) autoantigen binds precursors to 5S rRNA and tRNAs and also promotes their maturation in the nucleus. Separate from this function, human La has been shown to positively modulate the translation of IRES-containing mRNAs. During apoptosis, La is also a target for caspasemediated cleavage and dephosphorylation. ${ }^{135,136}$ Cleavage at the $\mathrm{C}$-terminus of the protein, downstream of $\mathrm{DEHD}_{371}$ or $\mathrm{DEHD}_{374}$ (Figure 3 ) results in the loss of the nuclear localisation signal, relocalising the truncated protein to the cytoplasm ${ }^{136}$ ). This relocalisation of La may promote the ability of the protein to influence translation initiation, including effects on internal initiation ${ }^{137}$ and the inhibition of PKR activity. ${ }^{138,139}$

\section{Effects of Modification of Initiation Factors on mRNA Translation during Apoptosis}

The progress of apoptosis is characterised by a general but incomplete inhibition of cap-dependent translation and a complex programme of changes involving several initiation factors that function in recruiting mRNA to the ribosome. Apoptosis-associated modifications include the specific fragmentation of proteins (elF4G, elF4B, elF3j), alterations in the state of phosphorylation of initiation factors (elF2 $\alpha$, elF4E, 4E-BP1) (reviewed in Morley ${ }^{1}$ and Clemens et al. $^{2}$ ) and interference with protein/protein interactions. An example of the latter is the caspase-mediated activation of the signalling molecule, Pak2, which impinges on elF4F complex assembly. Once cleaved, this kinase has the ability to phosphorylate Mnk1 and, without influencing its kinase activity, reduce the binding of Mnk1 to elF4GI ${ }^{140}$ prior to cleavage of elF4GI. Any or all of the above events could potentially contribute to the observed inhibition of protein synthesis, and it is likely that the relative importance of the various changes may be different at distinct stages of the ongoing apoptotic response. For example, in anti-Fas-treated Jurkat cells, it has been shown that the caspase-8-independent increase in elF $2 \alpha$ phosphorylation is associated with a reversible, general inhibition of protein synthesis and polysome disaggregation at early times. ${ }^{141}$ At slightly later times, this is followed by the irreversible cleavage of elF4GI, the loss of p70S6K activity and an increase in the binding of 4E-BP1 to elF4E. ${ }^{1}$

As several factors with different functions in translation are modified before and during the early stages of apoptosis, it is difficult to dissect the individual contributions of the changes observed to the overall regulation of protein synthesis. As with many other aspects of apoptosis, the mechanisms of translational downregulation are almost certainly multifactorial. In addition, other events occur that can have a major impact on global protein synthesis and/or the translation of specific mRNAs. For example, recent studies have identified significant degradation of some mRNA species at early times after treatment of cells with various inducers of apoptosis. ${ }^{142,143}$ There is also cleavage of $28 \mathrm{~S}$ rRNA in ribosomes in apoptotic cells, although this may be a somewhat later event. ${ }^{144}$ In spite of these uncertainties, with our knowledge of the roles of individual initiation factors, it is possible to identify several specific effects that can be predicted from the changes induced by the phosphorylation and/or cleavage of these proteins during the early stages of the induction of cell death.

\section{Effects of elF2 $\alpha$ phosphorylation and cleavage}

Increases in the extent of phosphorylation of elF2 $\alpha$ would be expected to have a strong impact on global protein synthesis because of the inhibitory effect of this modification on the guanine nucleotide exchange activity of elF2B. ${ }^{145}$ As far as we know, all cellular mRNAs require elF2 and elF2B activity for their translation. However, it is becoming clear that some mRNAs are less dependent than others on the availability of elF2-containing ternary complexes, and, in certain notable 
cases, the rate of translation of specific coding sequences in mRNAs with short upstream open-reading frames can even be enhanced by increased phosphorylation of elF2 $\alpha$ and decreased elF2B activity. ${ }^{146,147}$ Moreover, it has been reported that the truncated form of elF $2 \alpha$ that arises in apoptotic cells as a result of caspase activity shows very rapid exchange of GDP that is no longer dependent upon elF2B. ${ }^{97}$ Consistent with this, expression of the cleaved protein overcomes PKR-mediated translational suppression. ${ }^{98}$ These results suggest that the caspase-mediated cleavage of elF $2 \alpha$ may in fact render the protein constitutively active in a manner independent of its state of phosphorylation. This may have the effect of protecting protein synthesis from complete downregulation since a basal level of activity could presumably be maintained by the small fraction of the factor that is cleaved. This could be especially relevant for the continued translation of IRES-containing mRNAs (see below) since although the utilisation of these mRNAs is independent of changes in elF4G or 4E-BP function, it does require elF2 activity. However, such a possibility has not yet been demonstrated experimentally. It is also not known whether there is any functional relationship between elF2 $\alpha$ phosphorylation and the susceptibility of the protein to cleavage by caspases.

\section{Effects of modifications of the elF4F complex}

The modification of the elF4F complex observed in picornaviral infection, cutting the cap-binding components and the ribosome binding components, serves a clear function in allowing the translation of only the uncapped picornaviral mRNAs by internal ribosome entry. However, the very different modifications of the elF4F complex during apoptosis require us to make different hypotheses as to how such changes may assert themselves in those circumstances.

In several apoptotic systems, such as cycloheximidetreated BJAB cells and anti-Fas-treated Jurkat cells, cleavage of elF4GI results in the production of a modified form of elF4F, containing elF4E and elF4A, but with the central M-FAG fragment in place of full-length elF4GI (Figure 5). This complex, which is distinct from the steady-state elF4F complex observed during cell growth, remains stable for several hours in apoptosing cells before M-FAG is further degraded, with the loss of the elF4E binding site. ${ }^{141}$ As such, the modified elF4F complex present in apoptotic cells at early times may still be able to support either cap-dependent ${ }^{110}$ or -independent initiation. ${ }^{149}$ In addition, the decrease in the phosphorylation state of elF4E during apoptosis may reflect the activation of Pak2, ${ }^{140}$ but it could also be a consequence of elF4G cleavage because the binding site for the elF4E kinases, Mnk1/2, is not present in M-FAG. ${ }^{148}$

When HeLa cells are exposed to the cytotoxic ligand TRAIL, apoptosis is rapidly induced and translation rates are severely, but not completely, inhibited. ${ }^{105}$ The presence of either the c-myc or HRV2 IRES between the cistrons of a dicistronic luciferase reporter $\mathrm{mRNA}^{150}$ was able to maintain the translation of the downstream Firefly luciferase sequence under these conditions. In contrast, the translation of the upstream Renilla luciferase cistron, which is translated in a cap-dependent manner, was found to decrease over time.

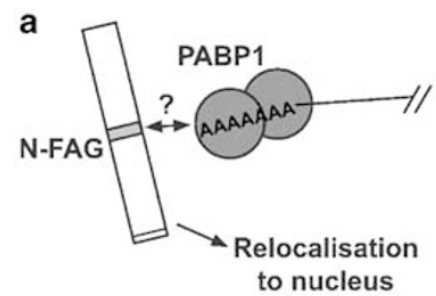

b
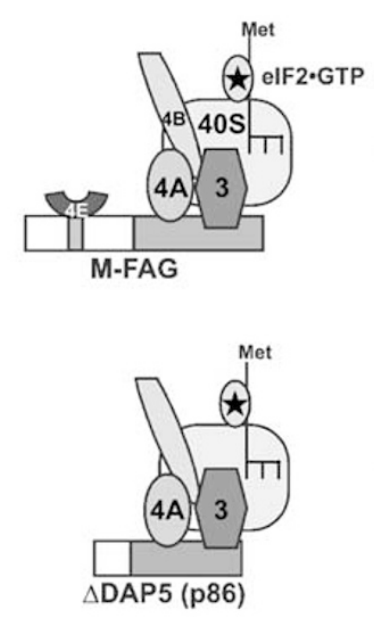
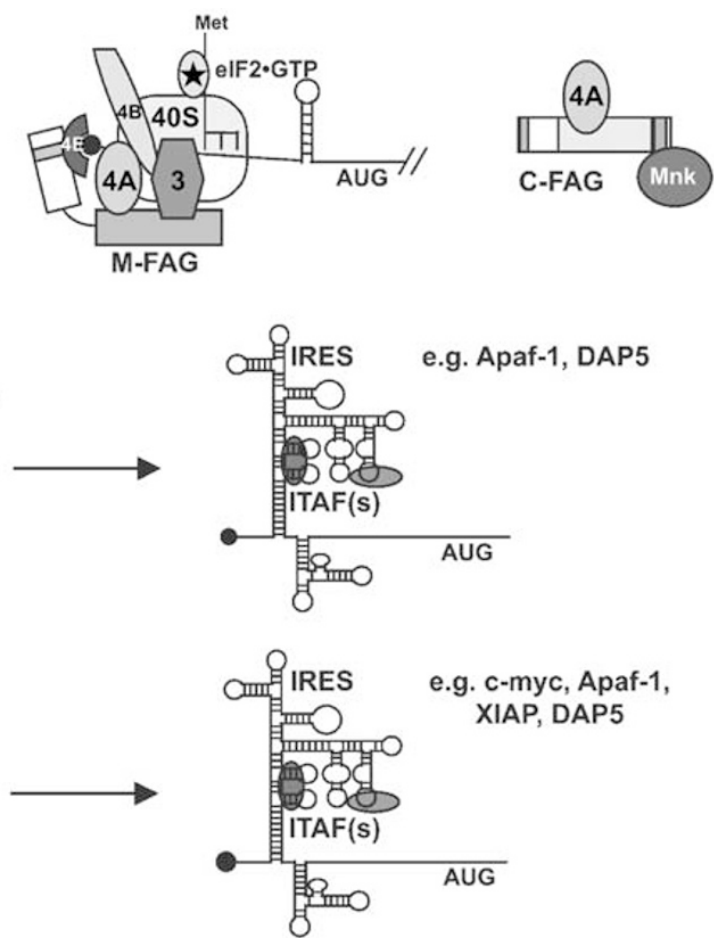

Figure 5 Translation initiation during apoptosis. (a) N-FAG has been postulated to be involved in sequestering PABP1. (Note, however, that N-FAG expressed from a CDNA is observed to relocalise to the nucleus without influencing the localisation of PABP1.) M-FAG is present in a modified elF4F complex, which may be able to direct some cap-dependent translation. A function for C-FAG is yet to be determined, but it may sequester Mnk1 and/or elF4A. (b) The modified elF4F complex, containing either M-FAG or cleaved DAP-5, is still able to maintain the translation of some, but not all, cellular IRES-containing mRNAs 
C-myc mRNA itself can initiate translation in either a capdependent manner or an IRES-dependent manner, ${ }^{151}$ and the continued expression of the c-myc protein from the IRES may be important for the later stages of apoptosis. Although a definite function is still not known, the c-myc protein may be important in activating the transcription of genes that are involved in ensuring the appropriate engulfment of the apoptotic cell. As the c-myc protein has a very short half-life (around $20 \mathrm{~min}^{152,153}$ ), it would have to be continuously synthesised to maintain suitable levels of the protein.

It has also been shown that the IRES present in the mRNA encoding the XIAP protein is still active during apoptosis. ${ }^{154,155}$ Moreover, the DAP5 IRES is used to maintain translation initiation during apoptosis in cells treated with anti-Fas antibodies. ${ }^{134}$ Work has also identified IRES activity within the $5^{\prime}$ UTR of the La mRNA, ${ }^{156}$ and it is tempting to hypothesise that the La protein may be able to regulate expression of itself at the level of translation initiation. These results suggest that this may be a common mechanism in ensuring maintenance of the expression of IRES specific trans-acting factors to allow translation of other IRES-driven messages under conditions when cap-dependent translation is compromised. However, it is clear that not all mRNAs that can be translated by an IRES-dependent mechanism continue to be translated during apoptosis. When dicistronic luciferase reporter plasmids containing the Apaf-1 and BAG-1 IRESs were transfected into HeLa cells and an apoptotic programme was induced by TRAIL, the Apaf-1 and BAG-1 IRESs were unable to maintain translation of the downstream Firefly luciferase reporter gene beyond the first $2 \mathrm{~h}$ of TRAIL treatment (MJ Coldwell, unpublished results). This is in contrast to the results seen with the c-myc and HRV2 IRESs, where Firefly luciferase expression was observed throughout an $8 \mathrm{~h}$ time course, after which $95 \%$ of the cells were apoptotic. ${ }^{105}$

The question still remains as to what actually drives the selective translation of these IRES-containing mRNAs during the apoptotic process. At this time, there is still some confusion over any possible role for the cleavage fragments of elF4GI in modulating translation rates during early apoptosis (Figure 5). N-FAG, which can be stable in apoptosing cells for at least $24 \mathrm{~h},{ }^{103}$ contains the PABP binding site and was postulated to inhibit cap-dependent translation initiation by sequestering PABP in an inactive complex that was unable to recycle ribosomes between rounds of termination and initiation. However, in vitro experiments using the reticulocyte lysate system and purified, recombinant N-FAG have suggested that this is probably not the case (SJ Morley, unpublished data). In addition, a lack of any effect of N-FAG on the translation of a number of dicistronic reporter genes expressed in 293 cells has confirmed these findings. ${ }^{157}$ Recent studies have shown that N-FAG actually accumulates in the nucleus and that this occurs due to the presence of a basic nuclear localisation signal in N-FAG (in the absence of the putative nuclear export signal that lies in the $\mathrm{C}$-terminus of elF4GI). These changes relocalise N-FAG into a cellular compartment where it cannot influence translation rates directly. ${ }^{158}$ Moreover, they occur without a concomitant relocalisation of PABP. However, it is unclear whether N-FAG is able to exert an effect on translation after the collapse of the nucleus that occurs at later stages of apoptosis. C-FAG, which is predominantly cytoplasmic, contains one of the elF4A binding sites and also the binding site for the elF4E-kinase Mnk1. However, it also does not influence translation rates in vitro (SJ Morley, unpublished data). Effects on IRES-driven translation are also unlikely to be a result of the cleavage of elF4GIl during apoptosis (Figure 4b). The N-FAG equivalent that lacks the KRRRK nuclear localisation signal found in elF4GI ${ }^{158}$ remains intact and is predicted to be cytoplasmic; whether this can influence translation rates is unknown at this time. Further cleavages of elF4GII at DKAD 851 and DVID 978 result in the production of fragments additional to those observed in the processing of elF4GI. ${ }^{104}$ The elF4A/elF3 binding sites are destroyed, suggesting that the fragments are unlikely to participate in any ongoing translation. An additional, noncanonical caspase-3 cleavage event at amino acid 1407 after an IESD sequence also bifurcates the elF4GIl counterpart of C-FAG (Figure 4b).

There has been one report that has suggested that M-FAG can influence the translation of reporter mRNAs containing a cellular IRES sequence. In this study, Apaf-I IRES-driven translation was responsive to the expression of M-FAG in cells that were not undergoing apoptosis. ${ }^{157}$ However, both our own unpublished work and an independent study have concluded that overexpression of M-FAG alone has no effect on c-myc, XIAP or Apaf-1 IRES-driven translation. ${ }^{159}$ The reasons for these differences are unclear, but the various studies have used different reporter systems, with various levels of expression of proteins in the cells. Alternatively, such assays may need to be carried out in cells during the early phases of apoptosis for consistent effects to be observed.

The most plausible candidate for modulating selective IRES-driven translation during apoptosis is DAP5. Studies have shown that DAP5 is a caspase-activated translation factor, able to maintain the translation of its own mRNA during apoptosis. ${ }^{134}$ Removal of the C-terminus of the protein allows it to stimulate IRES-driven translation and abrogates its ability to inhibit cap-dependent translation (Figure 5b). As such, the cleaved form of DAP5 (p86) has been demonstrated to stimulate translation from a reporter mRNA containing Apaf-1, c-myc or XIAP IRES sequences. ${ }^{157,159}$ Consequently, it has been proposed that DAP5 plays a central role in allowing the cell to rapidly and simultaneously upregulate expression of both pro- and antiapoptotic proteins for a short period of time, generating a fine balance between apoptosis and survival in the presence of the apoptotic trigger. Consistent with this is the report that the Apaf-1 and BAG-1 IRESs were unable to maintain reporter gene translation beyond the first $2 \mathrm{~h}$ of TRAIL treatment (MJ Coldwell, unpublished results). As Apaf1 is proapoptotic, the cell may not require new synthesis of the protein once the caspase cascade is underway. Similarly, although BAG-1 is an antiapoptotic protein, it can only inhibit the early stages of the apoptotic programme by enhancing the function of $\mathrm{Bcl}-2$. This protein is thought to prevent the release of cytochrome $c$ into the cytosol, where it can bind to Apaf-1 and activate the apoptosome. This part of the apoptotic pathway is upstream of the site of action of XIAP, a protein that is itself translated by a cap-independent mechanism and binds to caspases to prevent their activation. The Apaf-1, BAG-1 and XIAP proteins may be required to regulate the complex interplay between the pro- and antiapoptotic pathways during the initial stages of apoptosis. However, once the 
death of the cell is inevitable, only those IRESs required for maintenance of expression of short-lived proteins during the latter stages of apoptosis may remain functional. As a result of the cleavage of elF4GI, the late cleavage of PABP ${ }^{107}$ and the decreased ability of elF4E to participate in the initiation process, de novo cap-dependent translation would be severely inhibited. ${ }^{1}$

\section{Effects of modifications of 4E-BP1}

Several previous studies have shown that during the early phase of the cellular response to inducers of apoptosis, the extent of phosphorylation of 4E-BP1 decreases, ${ }^{83,101,124,125}$ and that the hypophosphorylated 4E-BP1 thus generated binds to elF4E in competition with elF4GI or II. This decreases the availability of the elF4F complex for initiation of translation. ${ }^{9,19}$ As described earlier, 4E-BP1 is also subject to cleavage (by both caspase and noncaspase enzymes), and it is possible that the cleavage product(s) may also serve as inhibitors of protein synthesis by sequestering elF4E and preventing association of the latter with elF4G ${ }^{126}(\mathrm{C}$ Constantinou and MJ Clemens, unpublished observations). Thus, the combined effects of the dephosphorylation of $4 \mathrm{E}$ BP1 and the cleavages of both elF4G and 4E-BP1 that occur prior to and during apoptosis appear to constitute a multifactorial mechanism leading to the sequestration of elF4E.

The downregulation of cap-dependent translation is inevitably a consequence of these changes, but again there is the possibility of differential effects on different mRNAs, depending on the requirement for the level of elF4F in the cell. Moreover, IRES-driven translation may well escape the inhibition altogether because it is an elF4E-independent process. A further variable that could influence the outcome of 4E-BP dephosphorylation and cleavage may be the ratio of elF4E to the 4E-BPs in the cell. High levels of elF4E expression are related to cell transformation and resistance to apoptosis, whereas $4 \mathrm{E}-\mathrm{BP}$ abundance can have growth inhibitory and proapoptotic effects. These cellular phenotypes may reflect the selective translation of different cell death-inhibiting or -promoting proteins, respectively, and such phenomena may in turn be influenced by the structures of the corresponding mRNAs for these critical proteins.

\section{Acknowledgements}

We are grateful to our colleagues for valuable discussions and ideas, several of which appear in various forms in this article. Research in our laboratories is supported by grants from The Wellcome Trust (SJ Morley and MJ Coldwell; 040800), the Leukaemia Research Fund, the Association for International Cancer Research and the Cancer Prevention Research Trust (MJ Clemens). SJ Morley is a Senior Research Fellow of The Wellcome Trust.

\section{References}

1. Morley SJ (2001) The regulation of elF4F during cell growth and cell death. Prog. Mol. Subcell. Biol. 27: 1-37
2. Clemens MJ, Bushell M, Jeffrey IW, Pain VM and Morley SJ (2000) Translation initiation factor modifications and the regulation of protein synthesis in apoptotic cells. Cell Death Differ. 7: 603-615

3. Hershey JWB and Merrick WC (2000) Pathway and mechanism of initiation of protein synthesis In Translational Control of Gene Expression Sonenberg N, Hershey JWB and Mathews MB (eds) (New York: Cold Spring Harbor Laboratory Press) pp. 33-88

4. Sonenberg N and Dever TE (2003) Eukaryotic translation initiation factors and regulators. Curr. Opin. Struct. Biol. 13: 56-63

5. Abbott CM and Proud CG (2004) Translation factors: in sickness and in health. Trends Biochem. Sci. 29: 25-31

6. Kaufman RJ (2004) Regulation of mRNA translation by protein folding in the endoplasmic reticulum. Trends Biochem. Sci. 29: 152-158

7. Marcotrigiano J, Gingras AC, Sonenberg N and Burley SK (1997) Cocrystal structure of the messenger RNA $5^{\prime}$ cap-binding protein (elF4E) bound to 7-methyl-GDP. Cell 89: 951-961

8. Mader S, Lee H, Pause A and Sonenberg N (1995) The translation initiation factor elF-4E binds to a common motif shared by the translation factor elF-4 gamma and the translational repressors 4E-binding proteins. Mol. Cell. Biol. 15: $4990-4997$

9. Marcotrigiano J, Gingras AC, Sonenberg N and Burley SK (1999) Capdependent translation initiation in eukaryotes is regulated by a molecular mimic of elF4G. Mol. Cell 3: 707-716

10. Ptushkina M, von der Haar T, Karim MM, Hughes JM and McCarthy JE (1999) Repressor binding to a dorsal regulatory site traps human elF4E in a high capaffinity state. EMBO J. 18: 4068-4075

11. Pain VM (1996) Initiation of protein synthesis in eukaryotic cells. Eur. J. Biochem. 236: 747-771

12. Dever TE (1999) Translation initiation: adept at adapting. Trends Biochem. Sci. 24: 398-403

13. Preiss T and Hentze MW (1999) From factors to mechanisms: translation and translational control in eukaryotes. Curr. Opin. Genet. Dev. 9: 515-521

14. Gingras AC, Raught B and Sonenberg N (1999) elF4 initiation factors: effectors of mRNA recruitment to ribosomes and regulators of translation. Annu. Rev. Biochem. 68: 913-963

15. Gingras AC, Raught B and Sonenberg N (2001) Control of translation by the target of rapamycin proteins. Prog. Mol. Subcell. Biol. 27: 143-174

16. Raught B, Gingras AC and Sonenberg N (2000) Regulation of ribosomal recruitment in eukaryotes In Translational Control of Gene Expression Sonenberg N, Hershey JWB and Mathews MB (eds) (New York: Cold Spring Harbor Laboratory Press) pp. 245-293

17. Scheper GC, van Kollenburg B, Hu J, Luo Y, Goss DJ and Proud CG (2002) Phosphorylation of eukaryotic initiation factor $4 \mathrm{E}$ markedly reduces its affinity for capped mRNA. J. Biol. Chem. 277: 3303-3309

18. Rousseau D, Gingras AC, Pause A and Sonenberg N (1996) The elF4Ebinding proteins 1 and 2 are negative regulators of cell growth. Oncogene 13: 2415-2420

19. Karim MM, Hughes JM, Warwicker J, Scheper GC, Proud CG and McCarthy JE (2001) A quantitative molecular model for modulation of mammalian translation by the elF4E-binding protein 1. J. Biol. Chem. 276: 20750-20757

20. Watkins SJ and Norbury CJ (2002) Translation initiation and its deregulation during tumorigenesis. Br. J. Cancer 86: 1023-1027

21. Clemens MJ (2004) Targets and mechanisms for the regulation of translation in malignant transformation. Oncogene 23: 3180-3188

22. Topisirovic I, Guzman ML, McConnell MJ, Licht JD, Culjkovic B, Neering SJ, Jordan CT and Borden KL (2003) Aberrant eukaryotic translation initiation factor 4E-dependent mRNA transport impedes hematopoietic differentiation and contributes to leukemogenesis. Mol. Cell. Biol. 23: 8992-9002

23. Zimmer SG, DeBenedetti A and Graff JR (2000) Translational control of malignancy: the mRNA cap-binding protein, elF-4E, as a central regulator of tumor formation, growth, invasion and metastasis. Anticancer Res. 20: 1343-1351

24. Li S, Takasu T, Perlman DM, Peterson MS, Burrichter D, Avdulov S, Bitterman PB and Polunovsky VA (2003) Translation factor elF4E rescues cells from Myc-dependent apoptosis by inhibiting cytochrome $c$ release. J. Biol. Chem. 278: 3015-3022

25. Polunovsky VA, Rosenwald IB, Tan AT, White J, Chiang L, Sonenberg N and Bitterman PB (1996) Translational control of programmed cell death: eukaryotic translation initiation factor $4 \mathrm{E}$ blocks apoptosis in growth-factor- 
restricted fibroblasts with physiologically expressed or deregulated Myc. Mol. Cell. Biol. 16: 6573-6581

26. Polunovsky VA, Gingras AC, Sonenberg N, Peterson M, Tan A, Rubins JB, Manivel JC and Bitterman PB (2000) Translational control of the antiapoptotic function of Ras. J. Biol. Chem. 275: 24776-24780

27. Marth JD, Overell RW, Meier KE, Krebs EG and Perlmutter RM (1988) Translational activation of the Ick proto-oncogene. Nature 332: 171-173

28. Carter PS, Jarquin-Pardo M and De Benedetti A (1999) Differential expression of Myc1 and Myc2 isoforms in cells transformed by elF4E: evidence for internal ribosome repositioning in the human c-myc $5^{\prime}$ UTR. Oncogene 18: 4326-4335

29. Tan A, Bitterman P, Sonenberg N, Peterson M and Polunovsky V (2000) Inhibition of Myc-dependent apoptosis by eukaryotic translation initiation factor $4 \mathrm{E}$ requires cyclin D1. Oncogene 19: 1437-1447

30. Chung J, Bachelder RE, Lipscomb EA, Shaw LM and Mercurio AM (2002) Integrin (alpha 6 beta 4) regulation of elF-4E activity and VEGF translation: a survival mechanism for carcinoma cells. J. Cell Biol. 158: 165-174

31. Yoder-Hill J, Pause A, Sonenberg N and Merrick WC (1993) The p46 subunit of eukaryotic initiation factor (elF)-4F exchanges with elF-4A. J. Biol. Chem. 268: $5566-5573$

32. Williams-Hill DM, Duncan RF, Nielsen PJ and Tahara SM (1997) Differential expression of the murine eukaryotic translation initiation factor isogenes elF4A(I) and elF4A(II) is dependent upon cellular growth status. Arch. Biochem. Biophys. 338: 111-120

33. Weinstein DC, Honore E and Hemmati-Brivanlou A (1997) Epidermal induction and inhibition of neural fate by translation initiation factor 4Alll. Development 124: 4235-4242

34. de la Cruz J, Kressler D and Linder P (1999) Unwinding RNA in Saccharomyces cerevisiae: DEAD-box proteins and related families. Trends Biochem. Sci. 24: 192-198

35. Li Q, Imataka H, Morino S, Rogers Jr. GW, Richter-Cook NJ, Merrick WC and Sonenberg N (1999) Eukaryotic translation initiation factor 4Alll (elF4AIII) is functionally distinct from elF4AI and elF4All. Mol. Cell. Biol. 19: 7336-7346

36. Pause A, Methot N, Svitkin Y, Merrick WC and Sonenberg N (1994) Dominant negative mutants of mammalian translation initiation factor elF-4A define a critical role for elF-4F in cap-dependent and cap-independent initiation of translation. EMBO J. 13: 1205-1215

37. Shibuya T, Tange TO, Sonenberg N and Moore MJ (2004) elF4Alll binds spliced mRNA in the exon junction complex and is essential for nonsensemediated decay. Nat. Struct. Mol. Biol. 11: 346-351

38. Palacios IM, Gatfield D, St Johnston D and Izaurralde E (2004) An elF4AIIIcontaining complex required for mRNA localization and nonsense-mediated mRNA decay. Nature 427: 753-757

39. Chan CC, Dostie J, Diem MD, Feng W, Mann M, Rappsilber J and Dreyfuss G (2004) elF4A3 is a novel component of the exon junction complex. RNA 10: 200-209

40. Rozen F, Edery I, Meerovitch K, Dever TE, Merrick WC and Sonenberg N (1990) Bidirectional RNA helicase activity of eucaryotic translation initiation factors 4A and 4F. Mol. Cell. Biol. 10: 1134-1144

41. Altmann M, Blum S, Wilson TM and Trachsel H (1990) The $5^{\prime}$-leader sequence of tobacco mosaic virus RNA mediates initiation- factor-4Eindependent, but still initiation-factor-4A-dependent translation in yeast extracts. Gene 91: 127-129

42. Merrick WC (1994) Eukaryotic protein synthesis: an in vitro analysis. Biochimie 76: 822-830

43. Methot N, Rom E, Olsen H and Sonenberg N (1997) The human homologue of the yeast Prt1 protein is an integral part of the eukaryotic initiation factor 3 complex and interacts with p170. J. Biol. Chem. 272: 1110-1116

44. Milburn SC, Hershey JW, Davies MV, Kelleher K and Kaufman RJ (1990) Cloning and expression of eukaryotic initiation factor $4 \mathrm{~B}$ CDNA: sequence determination identifies a common RNA recognition motif. EMBO J. 9: 2783-2790

45. Methot N, Pause A, Hershey JW and Sonenberg N (1994) The translation initiation factor elF-4B contains an RNA-binding region that is distinct and independent from its ribonucleoprotein consensus sequence. Mol. Cell. Biol. 14: $2307-2316$

46. Naranda T, Strong WB, Menaya J, Fabbri BJ and Hershey JW (1994) Two structural domains of initiation factor elF-4B are involved in binding to RNA. J. Biol. Chem. 269: 14465-14472
47. Richter-Cook NJ, Dever TE, Hensold JO and Merrick WC (1998) Purification and characterization of a new eukaryotic protein translation factor. Eukaryotic initiation factor 4H. J. Biol. Chem. 273: 7579-7587

48. Rogers Jr GW, Richter NJ and Merrick WC (1999) Biochemical and kinetic characterization of the RNA helicase activity of eukaryotic initiation factor $4 \mathrm{~A}$. J. Biol. Chem. 274: 12236-12244

49. Hentze MW (1997) elF4G: a multipurpose ribosome adapter? Science 275 : $500-501$

50. Morley SJ, Curtis PS and Pain VM (1997) elF4G: translation's mystery factor begins to yield its secrets. RNA 3: 1085-1104

51. Yan R, Rychlik W, Etchison D and Rhoads RE (1992) Amino acid sequence of the human protein synthesis initiation factor elF-4 gamma. J. Biol. Chem. 267: 23226-23231

52. Imataka H, Gradi A and Sonenberg N (1998) A newly identified N-terminal amino acid sequence of human elF4G binds poly(A)-binding protein and functions in poly(A)-dependent translation. EMBO J. 17: 7480-7489

53. Bradley CA, Padovan JC, Thompson TC, Benoit CA, Chait BT and Rhoads RE (2002) Mass spectrometric analysis of the N-terminus of translation initiation factor elF4G-1 reveals novel isoforms. J. Biol. Chem. 277: 12559-12571

54. Byrd MP, Zamora M and Lloyd RE (2002) Generation of multiple isoforms of eukaryotic translation initiation factor $4 \mathrm{Gl}$ by use of alternate translation initiation codons. Mol. Cell. Biol. 22: 4499-4511

55. McKendrick L, Thompson E, Ferreira J, Morley SJ and Lewis JD (2001) Interaction of eukaryotic translation initiation factor $4 G$ with the nuclear capbinding complex provides a link between nuclear and cytoplasmic functions of the $m(7)$ guanosine cap. Mol. Cell. Biol. 21: 3632-3641

56. Lejeune F, Ranganathan AC and Maquat LE (2004) elF4G is required for the pioneer round of translation in mammalian cells. Nat. Struct. Mol. Biol. 11: 992-1000

57. Jacobson A and Peltz SW (1996) Interrelationships of the pathways of mRNA decay and translation in eukaryotic cells. Annu. Rev. Biochem. 65: 693-739

58. Gallie DR (1996) Translational control of cellular and viral mRNAs. Plant Mol. Biol. 32: 145-158

59. Tarun Jr SZ, Wells SE, Deardorff JA and Sachs AB (1997) Translation initiation factor elF4G mediates in vitro poly(A) tail-dependent translation. Proc. Natl. Acad. Sci. USA 94: 9046-9051

60. Sachs AB, Sarnow $P$ and Hentze MW (1997) Starting at the beginning, middle, and end: translation initiation in eukaryotes. Cell 89: 831-838

61. Wickens M, Anderson P and Jackson RJ (1997) Life and death in the cytoplasm: messages from the $3^{\prime}$ end. Curr. Opin. Genet. Dev. 7: 220-232

62. Le H, Tanguay RL, Balasta ML, Wei CC, Browning KS, Metz AM, Goss DJ and Gallie DR (1997) Translation initiation factors elF-iso4G and elF-4B interact with the poly $(A)$-binding protein and increase its RNA binding activity. J. Biol. Chem. 272: 16247-16255

63. Wells SE, Hillner PE, Vale RD and Sachs AB (1998) Circularisation of mRNA by eukaryotic translation initiation factors. Mol. Cell 2: 135-140

64. Gray N and Wickens M (1998) Control of translation initiation in animals. Annu. Rev. Cell Dev. Biol. 14: 399-458

65. Sachs AB (2000) Physical and functional interactions between the mRNA cap structure and the poly $(\mathrm{A})$ tail In Translational Control of Gene Expression Sonenberg N, Hershey JWB and Mathews MB (eds) (New York: Cold Spring Harbor Laboratory Press) pp. 447-465

66. Bi X and Goss DJ (2000) Wheat germ poly(A)-binding protein increases the ATPase and the RNA helicase activity of translation initiation factors elF4A, elF4B, and elF-iso4F. J. Biol. Chem. 275: 17740-17746

67. Haghighat A and Sonenberg N (1997) elF4G dramatically enhances the binding of elF4E to the mRNA $5^{\prime}$-cap structure. J. Biol. Chem. 272: 21677-21680

68. Raught B, Gingras AC, Gygi SP, Imataka H, Morino S, Gradi A, Aebersold R and Sonenberg N (2000) Serum-stimulated, rapamycin-sensitive phosphorylation sites in the eukaryotic translation initiation factor 4GI. EMBO J. 19: 434-444

69. Morley SJ and Traugh JA (1990) Differential stimulation of phosphorylation of initiation factors elF-4F, elF-4B, elF-3, and ribosomal protein $S 6$ by insulin and phorbol esters. J. Biol. Chem. 265: 10611-10616

70. Morley SJ and Traugh JA (1993) Stimulation of translation in 3T3-L1 cells in response to insulin and phorbol ester is directly correlated with increased 
phosphate labelling of initiation factor (elF-)4F and ribosomal protein S6. Biochimie 75: 985-989

71. Morley SJ and Pain VM (1995) Hormone-induced meiotic maturation in Xenopus oocytes occurs independently of p70s6k activation and is associated with enhanced initiation factor (elF)-4F phosphorylation and complex formation. J. Cell Sci. 108: 1751-1760

72. Morley SJ and Pain VM (1995) Translational regulation during activation of porcine peripheral blood lymphocytes: association and phosphorylation of the alpha and gamma subunits of the initiation factor complex elF-4F. Biochem. J. 312: 627-635

73. Fraser CS, Pain VM and Morley SJ (1999) The association of initiation factor 4F with poly $(\mathrm{A})$-binding protein is enhanced in serum-stimulated Xenopus kidney cells. J. Biol. Chem. 274: 196-204

74. Pyronnet S, Dostie J and Sonenberg N (2001) Suppression of cap-dependent translation in mitosis. Genes Dev. 15: 2083-2093

75. Qin H, Raught B, Sonenberg N, Goldstein EG and Edelman AM (2003) Phosphorylation screening identifies translational initiation factor 4 Gll as an intracellular target of $\mathrm{Ca}(2+)$ /calmodulin-dependent protein kinase I. J. Biol. Chem. 278: 48570-48579

76. Browning KS, Gallie DR, Hershey JW, Hinnebusch AG, Maitra U, Merrick WC and Norbury $C$ (2001) Unified nomenclature for the subunits of eukaryotic initiation factor 3. Trends Biochem. Sci. 26: 284

77. Fraser CS, Lee JY, Mayeur GL, Bushell M, Doudna JA and Hershey JW (2004) The j-subunit of human translation initiation factor elF3 is required for the stable binding of elF3 and its subcomplexes to $40 \mathrm{~S}$ ribosomal subunits in vitro. J. Biol. Chem. 279: 8946-8956

78. Deckwerth TL and Johnson EM (1993) Temporal analysis of events associated with programmed cell death (apoptosis) of sympathetic neurons deprived of nerve growth factor. J. Cell Biol. 123: 1207-1222

79. Zhou BB, Li HL, Yuan JY and Kirschner MW (1998) Caspase-dependent activation of cyclin-dependent kinases during Fas-induced apoptosis in Jurkat cell lines. Proc. Natl. Acad. Sci. USA 95: 6785-6790

80. Scott CE and Adebodun F (1999) 13C-NMR investigation of protein synthesis during apoptosis in human leukemic cell lines. J. Cell. Physiol. 181: 147-152

81. Morley SJ, McKendrick L and Bushell M (1998) Cleavage of translation initiation factor 4G (elF4G) during anti-Fas IgM-induced apoptosis does not require signalling through $\mathrm{p} 38$ mitogen-activated protein (MAP) kinase. FEBS Lett. 438: 41-48

82. Morley SJ, Jeffrey I, Bushell M, Pain VM and Clemens MJ (2000) Differential requirements for caspase-8 activity in the mechanism of phosphorylation of elF2alpha, cleavage of elF4GI and signaling events associated with the inhibition of protein synthesis in apoptotic Jurkat $T$ cells. FEBS Lett. 477: 229-236

83. Jeffrey IW, Bushell M, Tilleray VJ, Morley SJ and Clemens MJ (2002) Inhibition of protein synthesis in apoptosis: differential requirements by the tumour necrosis factor $\alpha$ family and a DNA damaging agent for caspases and the double-stranded RNA-dependent protein kinase. Cancer Res. 62: 2272-2280

84. Donze O, Deng J, Curran J, Sladek R, Picard D and Sonenberg N (2004) The protein kinase PKR: a molecular clock that sequentially activates survival and death programs. EMBO J. 23: 564-571

85. Hsu LC, Park JM, Zhang K, Luo JL, Maeda S, Kaufman RJ, Eckmann L, Guiney DG and Karin M (2004) The protein kinase PKR is required for macrophage apoptosis after activation of Toll-like receptor 4. Nature 428: 341-345

86. Gong B and Almasan A (2000) Apo2 ligand/TNF-related apoptosis-inducing ligand and death receptor 5 mediate the apoptotic signaling induced by ionizing radiation in leukemic cells. Cancer Res. 60: 5754-5760

87. Clodi K, Wimmer D, Li Y, Goodwin R, Jaeger U, Mann G, Gadner H and Younes A (2000) Expression of tumour necrosis factor (TNF)-related apoptosis-inducing ligand (TRAIL) receptors and sensitivity to TRAIL-induced apoptosis in primary B-cell acute lymphoblastic leukaemia cells. Br. J. Haematol. 111: 580-586

88. Altucci L, Rossin A, Raffelsberger W, Reitmair A, Chomienne C and Gronemeyer H (2001) Retinoic acid-induced apoptosis in leukemia cells is mediated by paracrine action of tumor-selective death ligand TRAIL. Nat. Med. 7: 680-686

89. Uno K, Inukai T, Kayagaki N, Goi K, Sato H, Nemoto A, Takahashi K, Kagami K, Yamaguchi N, Yagita H, Okumura K, Koyama-Okazaki T, Suzuki T, Sugita
K and Nakazawa S (2003) TNF-related apoptosis-inducing ligand (TRAIL) frequently induces apoptosis in Philadelphia chromosome-positive leukemia cells. Blood 101: 3658-3667

90. Jones DT, Ganeshaguru K, Mitchell WA, Foroni L, Baker RJ, Prentice HG, Mehta $A B$ and Wickremasinghe RG (2003) Cytotoxic drugs enhance the ex vivo sensitivity of malignant cells from a subset of acute myeloid leukaemia patients to apoptosis induction by tumour necrosis factor receptor-related apoptosis-inducing ligand. Br. J. Haematol. 121: 713-720

91. Walczak H, Miller RE, Ariail K, Gliniak B, Griffith TS, Kubin M, Chin W, Jones J, Woodward A, Le T, Smith C, Smolak P, Goodwin RG, Rauch CT, Schuh JC and Lynch DH (1999) Tumoricidal activity of tumor necrosis factor-related apoptosis-inducing ligand in vivo. Nat. Med. 5: 157-163

92. Ashkenazi A, Pai RC, Fong S, Leung S, Lawrence DA, Marsters SA, Blackie C, Chang L, McMurtrey AE, Hebert A, DeForge L, Koumenis IL, Lewis D, Harris L, Bussiere J, Koeppen H, Shahrokh Z and Schwall RH (1999) Safety and antitumor activity of recombinant soluble Apo2 ligand. J. Clin. Invest. 104: 155-162

93. Kischkel FC, Hellbardt S, Behrmann I, Germer M, Pawlita M, Krammer PH and Peter ME (1995) Cytotoxicity-dependent APO-1 (Fas/CD95)-associated proteins form a death-inducing signaling complex (DISC) with the receptor. EMBO J. 14: 5579-5588

94. Bratton SB, MacFarlane M, Cain K and Cohen GM (2000) Protein complexes activate distinct caspase cascades in death receptor and stress-induced apoptosis. Exp. Cell Res. 256: 27-33

95. Peter ME and Krammer PH (2003) The CD95(APO-1/Fas) DISC and beyond. Cell Death Differ. 10: 26-35

96. Saelens $X$, Kalai M and Vandenabeele $P$ (2001) Translation inhibition in apoptosis - caspase-dependent PKR activation and elF2- $\alpha$ phosphorylation. J. Biol. Chem. 276: 41620-41628

97. Marissen WE, Guo Y, Thomas AAM, Matts RL and Lloyd RE (2000) Identification of caspase 3-mediated cleavage and functional alteration of eukaryotic initiation factor $2 \alpha$ in apoptosis. J. Biol. Chem. 275: 9314-9323

98. Satoh S, Hijikata M, Handa H and Shimotohno K (1999) Caspase-mediated cleavage of eukaryotic translation initiation factor subunit 2alpha. Biochem J. 342: $65-70$

99. Clemens MJ, Bushell M and Morley SJ (1998) Degradation of eukaryotic polypeptide chain initiation factor (elF) $4 G$ in response to induction of apoptosis in human lymphoma cell lines. Oncogene 17: 2921-2931

100. Bushell M, Wood W, Jänicke RU, Clemens MJ and Morley SJ (1999) Caspase- 3 is necessary and sufficient for cleavage of protein eukaryotic initiation factor 4G during apoptosis. FEBS Lett. 451: 332-336

101. Bushell M, Wood W, Clemens MJ and Morley SJ (2000) Changes in integrity and association of eukaryotic protein synthesis initiation factors during apoptosis. Eur. J. Biochem. 267: 1083-1091

102. Bushell M, Poncet D, Marissen WE, Flotow H, Lloyd RE, Clemens MJ and Morley SJ (2000) Cleavage of polypeptide chain initiation factor elF4GI during apoptosis in lymphoma cells: characterisation of an internal fragment generated by caspase-3-mediated cleavage. Cell Death Differ. 7: 628-636

103. Marissen WE and Lloyd RE (1998) Eukaryotic translation initiation factor $4 G$ is targeted for proteolytic cleavage by caspase 3 during inhibition of translation in apoptotic cells. Mol. Cell. Biol. 18: 7565-7574

104. Marissen WE, Gradi A, Sonenberg N and Lloyd RE (2000) Cleavage of eukaryotic translation initiation factor 4Gll correlates with translation inhibition during apoptosis. Cell Death Differ. 7: 1234-1243

105. Stoneley M, Chappell SA, Jopling CL, Dickens M, MacFarlane M and Willis AE (2000) C-Myc protein synthesis is initiated from the internal ribosome entry segment during apoptosis. Mol. Cell. Biol. 20: 1162-1169

106. Gradi A, Imataka H, Svitkin YV, Rom E, Raught B, Morino S and Sonenberg N (1998) A novel functional human eukaryotic translation initiation factor $4 \mathrm{G}$. Mol. Cell. Biol. 18: 334-342

107. Marissen WE, Triyoso D, Younan P and Lloyd RE (2004) Degradation of poly $(A)$ binding protein in apoptotic cells and linkage to translation regulation. Apoptosis 9: 67-75

108. Ventoso I, Blanco R, Perales C and Carrasco L (2001) HIV-1 protease cleaves eukaryotic initiation factor $4 \mathrm{G}$ and inhibits cap-dependent translation. Proc. Natl. Acad. Sci. USA 98: 12966-12971

109. Ohlmann T, Prevot D, Decimo D, Roux F, Garin J, Morley SJ and Darlix JL (2002) In vitro cleavage of elF4GI but not elF4GIl by HIV-1 protease and its 
effects on translation in the rabbit reticulocyte lysate system. J. Mol. Biol. 318: 9-20

110. Morino S, Imataka H, Svitkin YV, Pestova TV and Sonenberg N (2000) Eukaryotic translation initiation factor $4 \mathrm{E}$ (elF4E) binding site and the middle one-third of elF4GI constitute the core domain for cap-dependent translation, and the $\mathrm{C}$-terminal one-third functions as a modulatory region. Mol. Cell. Biol. 20: $468-477$

111. Gingras AC, Raught B, Gygi SP, Niedzwiecka A, Miron M, Burley SK Polakiewicz RD, Wyslouch-Cieszynska A, Aebersold R and Sonenberg N (2001) Hierarchical phosphorylation of the translation inhibitor 4E-BP1. Genes Dev. 15: 2852-2864

112. Gingras AC, Raught $B$ and Sonenberg N (2001) Regulation of translation initiation by FRAP/mTOR. Genes Dev. 15: 807-826

113. Raught B, Gingras AC and Sonenberg N (2001) The target of rapamycin (TOR) proteins. Proc. Natl. Acad. Sci. USA 98: 7037-7044

114. Ly C, Arechiga AF, Melo JV, Walsh CM and Ong ST (2003) Bcr-Abl kinase modulates the translation regulators ribosomal protein $\mathrm{S} 6$ and 4E-BP1 in chronic myelogenous leukemia cells via the mammalian target of rapamycin. Cancer Res. 63: 5716-5722

115. Dilling MB, Germain GS, Dudkin L, Jayaraman AL, Zhang X, Harwood FC and Houghton PJ (2002) 4E-binding proteins, the suppressors of eukaryotic initiation factor $4 \mathrm{E}$, are down-regulated in cells with acquired or intrinsic resistance to rapamycin. J. Biol. Chem. 277: 13907-13917

116. Mita MM, Mita A and Rowinsky EK (2003) The molecular target of rapamycin (mTOR) as a therapeutic target against cancer. Cancer Biol. Ther. 2: S169-77

117. Sawyers CL (2003) Will mTOR inhibitors make it as cancer drugs? Cancer Cell. 4: 343-348

118. Hidalgo M and Rowinsky EK (2000) The rapamycin-sensitive signal transduction pathway as a target for cancer therapy. Oncogene 19: 6680-6686

119. Salaun P, Pyronnet S, Morales J, Mulner-Lorillon O, Belle R, Sonenberg N and Cormier $\mathrm{P}$ (2003) elF4E/4E-BP dissociation and 4E-BP degradation in the first mitotic division of the sea urchin embryo. Dev. Biol. 255: 428-439

120. Karin $M$ and Ben-Neriah $Y(2000)$ Phosphorylation meets ubiquitination: the control of NF-[kappa]B activity. Annu. Rev. Immunol. 18: 621-663

121. Almond JB and Cohen GM (2002) The proteasome: a novel target for cancer chemotherapy. Leukemia 16: 433-443

122. Aberle H, Bauer A, Stappert J, Kispert A and Kemler R (1997) Beta-catenin is a target for the ubiquitin-proteasome pathway. EMBO J. 16: 3797-3804

123. Chernov MV, Bean LJ, Lerner N and Stark GR (2001) Regulation of ubiquitination and degradation of p53 in unstressed cells through C-terminal phosphorylation. J. Biol. Chem. 276: 31819-31824

124. Tee AR and Proud CG (2000) DNA-damaging agents cause inactivation of translational regulators linked to mTOR signaling. Oncogene 19: 3021-3031

125. Tee AR and Proud CG (2001) Staurosporine inhibits phosphorylation of translational regulators linked to mTOR. Cell Death Differ. 8: 841-849

126. Tee AR and Proud CG (2002) Caspase cleavage of initiation factor $4 \mathrm{E}$-binding protein 1 yields a dominant inhibitor of cap-dependent translation and reveals a novel regulatory motif. Mol. Cell. Biol. 22: 1674-1683

127. Methot N, Song MS and Sonenberg N (1996) A region rich in aspartic acid, arginine, tyrosine, and glycine (DRYG) mediates eukaryotic initiation factor $4 \mathrm{~B}$ (elF4B) self-association and interaction with elF3. Mol. Cell. Biol. 16: 53285334

128. Block KL, Vornlocher HP and Hershey JW (1998) Characterization of cDNAs encoding the p44 and p35 subunits of human translation initiation factor elF3. J. Biol. Chem. 273: 31901-31908

129. Valasek L, Phan L, Schoenfeld LW, Valaskova V and Hinnebusch AG (2001) Related elF3 subunits TIF32 and HCR1 interact with an RNA recognition motif in PRT1 required for elF3 integrity and ribosome binding. EMBO J. 20: 891-904

130. Imataka H, Olsen HS and Sonenberg N (1997) A new translational regulator with homology to eukaryotic translation initiation factor $4 \mathrm{G}$. EMBO J. 16 817-825

131. Levy-Strumpf N, Deiss LP, Berissi H and Kimchi A (1997) DAP-5, a novel homolog of eukaryotic translation initiation factor $4 \mathrm{G}$ isolated as a putative modulator of gamma interferon-induced programmed cell death. Mol. Cell. Biol. 17: 1615-1625

132. Yamanaka S, Poksay KS, Arnold KS and Innerarity TL (1997) A novel translational repressor mRNA is edited extensively in livers containing tumours caused by the trans-gene expression of the apoB mRNA-editing enzyme. Genes Dev. 11: 321-333

133. Yamanaka S, Zhang XY, Maeda M, Miura K, Wang S, Farese Jr RV, Iwao H and Innerarity TL (2000) Essential role of NAT1/p97/DAP5 in embryonic differentiation and the retinoic acid pathway. EMBO J. 19: 5533-5541

134. Henis-Korenblit S, Levy Strumpf N, Goldstaub D and Kimchi A (2000) A novel form of DAP5 protein accumulates in apoptotic cells as a result of caspase cleavage and internal ribosome entry site-mediated translation. Mol. Cell. Biol. 20: $496-506$

135. Rutjes SA, Utz PJ, van der Heijden A, Broekhuis $C$, van Venrooij WJ and Pruijn GJ (1999) The La (SS-B) autoantigen, a key protein in RNA biogenesis, is dephosphorylated and cleaved early during apoptosis. Cell Death Differ. 6: 976-986

136. Ayukawa K, Taniguchi S, Masumoto J, Hashimoto S, Sarvotham H, Hara A, Aoyama T and Sagara J (2000) La autoantigen is cleaved in the $\mathrm{COOH}$ terminus and loses the nuclear localization signal during apoptosis. J. Biol. Chem. 275: 34465-34470

137. Meerovitch K, Svitkin YV, Lee HS, Lejbkowicz F, Kenan DJ, Chan EK, Agol VI, Keene JD and Sonenberg N (1993) La autoantigen enhances and corrects aberrant translation of poliovirus RNA in reticulocyte lysate. J. Virol. 67: 3798-3807

138. James MC, Jeffrey IW, Pruijn GJ, Thijssen JP and Clemens MJ (1999) Translational control by the $\mathrm{La}$ antigen. Structure requirements for rescue of the double-stranded RNA-mediated inhibition of protein synthesis. Eur. J. Biochem. 266: 151-162

139. Xiao Q, Sharp TV, Jeffrey IW, James MC, Pruijn GJ, van Venrooij WJ and Clemens MJ (1994) The La antigen inhibits the activation of the interferoninducible protein kinase PKR by sequestering and unwinding double-stranded RNA. Nucleic Acids Res. 22: 2512-2518

140. Orton KC, Ling J, Waskiewicz AJ, Cooper JA, Merrick WC, Korneeva NL, Rhoads RE, Sonenberg N and Traugh JA (2004) Phosphorylation of Mnk1 by caspase-activated Pak2/gamma-PAK inhibits phosphorylation and interaction of elF4G with Mnk. J. Biol. Chem. 279: 38649-38657

141. Morley SJ and Pain VM (2001) Proteasome inhibitors and immunosuppressive drugs promote the cleavage of elF4GI and elF4GIl by caspase-8-independent mechanisms in Jurkat T cell lines. FEBS Lett. 503: 206-212

142. Del Prete MJ, Robles MS, Guao A, Martinez-A C, Izquierdo M and GarciaSanz JA (2002) Degradation of cellular mRNA is a general early apoptosisinduced event. FASEB J. 16: 2003-2005

143. Bushell M, Stoneley M, Sarnow P and Willis AE (2004) Translation inhibition during the induction of apoptosis: RNA or protein degradation? Biochem. Soc. Trans. 32: 606-610

144. King KL, Jewell CM, Bortner CD and Cidlowski JA (2000) 28S ribosome degradation in lymphoid cell apoptosis: evidence for caspase and Bcl-2dependent and -independent pathways. Cell Death Differ. 7: 994-1001

145. Proud CG (2001) Regulation of eukaryotic initiation factor elF2B. Prog. Mol. Subcell. Biol. 26: 95-114

146. Hinnebusch AG (1997) Translational regulation of yeast GCN4 - a window on factors that control initiator-tRNA binding to the ribosome. J. Biol. Chem. 272: 21661-21664

147. Lu PD, Harding HP and Ron D (2004) Translation reinitiation at alternative open reading frames regulates gene expression in an integrated stress response. J. Cell Biol. 167: 27-33

148. Pyronnet S, Imataka H, Gingras AC, Fukunaga R, Hunter T and Sonenberg $N$ (1999) Human eukaryotic translation initiation factor $4 \mathrm{G}$ (elF4G) recruits mnk1 to phosphorylate elF4E. EMBO J. 18: 270-279

149. De Gregorio E, Preiss T and Hentze MW (1999) Translation driven by an elF4G core domain in vivo. EMBO J. 18: 4865-4874

150. Stoneley M, Paulin FEM, Le Quesne JPC, Chappell SA and Willis AE (1998) C-Myc $5^{\prime}$ untranslated region contains an internal ribosome entry segment. Oncogene 16: 423-428

151. Stoneley M, Subkhankulova T, Le Quesne JPC, Coldwell MJ, Jopling CL, Belsham GJ and Willis AE (2000) Analysis of the c-myc IRES; a potential role for cell-type specific trans-acting factors and the nuclear compartment. Nucleic Acids Res. 28: 687-694

152. Hann SR and Eisenman RN (1984) Proteins encoded by the human c-myc oncogene: differential expression in neoplastic cells. Mol. Cell. Biol. 4: 2486-2497 
153. West MJ, Stoneley M and Willis AE (1998) Translational induction of the c-myc oncogene via activation of the FRAP/TOR signalling pathway. Oncogene 17: $769-780$

154. Holcik M, Lefebvre C, Yeh C, Chow T and Korneluk RG (1999) A new internalribosome-entry-site motif potentiates XIAP-mediated cytoprotection. Nat. Cell Biol. 1: 190-192

155. Holcik M, Yeh C, Korneluk RG and Chow T (2000) Translational upregulation of $\mathrm{X}$-linked inhibitor of apoptosis (XIAP) increases resistance to radiation induced cell death. Oncogene 19: 4174-4177

156. Carter MS and Sarnow P (2000) Distinct mRNAs that encode La autoantigen are differentially expressed and contain internal ribosome entry sites. J. Biol. Chem. 275: 28301-28307
157. Nevins TA, Harder ZM, Korneluk RG and Holcik M (2003) Distinct regulation of internal ribosome entry site-mediated translation following cellular stress is mediated by apoptotic fragments of elF4G translation initiation factor family members elF4GI and p97/DAP5/NAT1. J. Biol. Chem. 278: 3572-3579

158. Coldwell MJ, Hashemzadeh-Bonehi L, Hinton TM, Morley SJ and Pain VM (2004) Expression of fragments of translation initiation factor elF4GI reveals a nuclear localisation signal within the $\mathrm{N}$-terminal apoptotic cleavage fragment N-FAG. J. Cell Sci. 117: 2545-2555

159. Henis-Korenblit S, Shani G, Sines T, Marash L, Shohat G and Kimchi A (2002) The caspase-cleaved DAP5 protein supports internal ribosome entry site-mediated translation of death proteins. Proc. Natl. Acad. Sci. USA 99: 5400-5405 